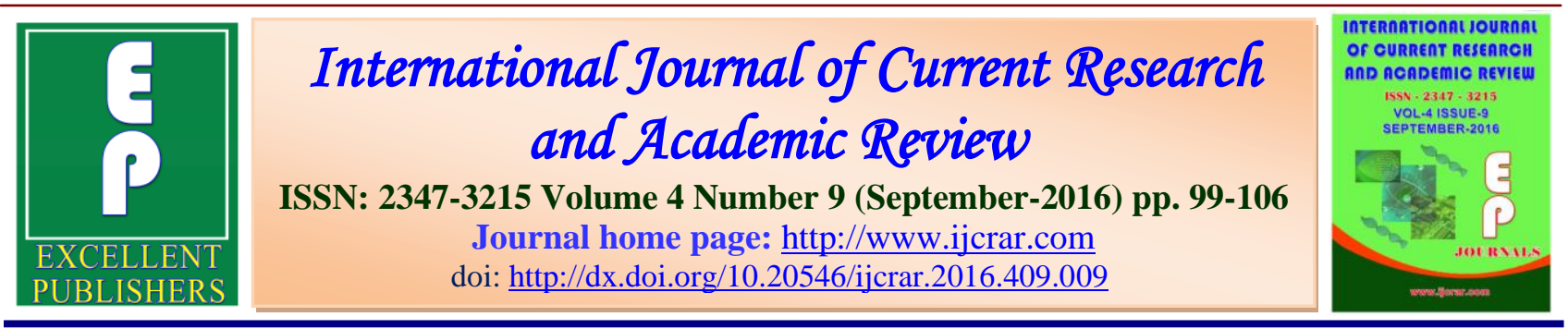

\title{
Relationship among Some Immunoglobulins, Complement Protein C3 and Urinary Tract Infection of Women Caused by Gram Negative Bacilli in Kirkuk, Iraq
}

\author{
Najdat B. Mahdi, Sahla K. Abbas and Khalaf J. Ahmed* \\ Department of Biology, Collage of Science, University of Kirkuk, Iraq \\ *Corresponding author
}

\begin{tabular}{|l|l|}
\hline \multirow{2}{*}{ KEYWORDS } & A B S T R A C T \\
\cline { 2 - 3 } $\begin{array}{l}\text { Urinary Tract } \\
\text { Infection, }\end{array}$ & $\begin{array}{l}\text { The urinary tract is one of the most frequent sites for happening of bacterial } \\
\text { infections, especially in women. Common bacteria related with urinary tract }\end{array}$ \\
Immunoglobulins, \\
$\begin{array}{l}\text { infection were isolated and identified from } 400 \text { women patients aged from } 14 \\
\text { to } 60 \text { years in Azadi Teaching Hospital and General Kirkuk Hospital. The } \\
\text { protein C3. }\end{array}$ & $\begin{array}{l}\text { levels of immunoglobulins (IgM, IgG and IgA) and complement protein C3 } \\
\text { were evaluated in women infected by Escherichia coli and non infected } \\
\text { women with UTI. The results refer to the dominance of Escherichia coli and } \\
\text { high significant }(\mathrm{P} \leq 0.001) \text { was observed for levels of immunoglobulins IgM, } \\
\text { IgG and IgA that ranged (295.91 } \pm 12.51,1758.77 \pm 28.52 \text { and } 473 \pm 14.67) \\
\text { mg/dl respectively. Also there was significant increased }(\mathrm{P} \leq 0.001) \text { in level } \\
\text { of complement protein C3 ranged }(195.13 \pm 10.53) \text { mg/dl. }\end{array}$ \\
\hline
\end{tabular}

\section{Introduction}

Urinary tract infection is an infection of different parts of body's excretory system which involve a bladder, urethra, two ureters, and two kidneys. It is the second most frequent kind of infection in the body (Schappert and Rechtsteiner, 2008). About 10.8 million patients in United States visited an emergency development for treatment of UTI (Sammon et al., 2014). Bacterial organisms which cause UTI may involve Escherichia coli, Klepsiella, Pseudomonas, Proteus mirabilis and Enterococcus fecalis (Mahmood, 2011; Dromigny, 2005).
Women are more prone to develop urinary tract infection because the wide and short urethra and its proximity to anus. Bacteria can simply enter urethra from rectum and attack urethra, bladder, ureters and may even damage kidney function (Kolawole et al., 2009; AAFF, 2004). Urinary tract infection may include the upper and the lower tract or only the lower urinary tract. The term cystitis has been used to express the symptoms involving dysuria, urgency, frequency and occasionally suprapubic tenderness. Acute pyelonephritis shows the 
clinical symptoms characterized by loin pain or tenderness or both and fever often associated with dysuria, urgency and frequency (Mandell, 2005).

Presence of bacterial growth more than 100000 organism per milliliter from correctly midstream "clean catch" urine sample indicate infection (Stamm and Schaeffer, 2002). Complement system is part of the innate immune mechanisms which consist of over (30) proteins, including serum proteins and cell membrane receptors (Abbas et al., 2010; Janeway, 2001). These proteins are produced by liver cells, tissue macrophages, blood monocytes and epithelial cells of the genitourinal tract and gastrointestinal tract. The activation of three pathways leads to generate the protease C3 convertase. After series of complement proteins activation (according to type of pathway) lead to form C5b6789 which is represent membrane attack complex (MAC), this complex forms membrane channel which causes osmotic lyses of the target cell (Andreas et al., 2013; Goldman and Prabhakar, 2001).

One of the first defense mechanism to the uropathogen is the local immune system on the mucosa of the urinary tract, which include urinary immunoglobulin (Secretory IgA). It has been express that local immunoglobulin can connect to the bacteria and inhibit their attachment to mucosal surfaces (Kantele et al., 2008; Thumbikat et al., 2006).

This study aimed to determine the gram negative bacilli causing urinary tract infection and evaluation the levels of serum immunoglobulins (IgM, $\operatorname{IgG}$ and $\operatorname{Ig} \mathrm{A}$ ) and complement protein $\mathrm{C} 3$ in women infected with urinary tract infection caused by Escherichia coli.
Materials and Methods

\section{Collection of serum and urine samples}

This study was included collection four hundred serum and urine samples from non pregnant women aged range $(14-60)$ years come to General Kirkuk Hospital and Azidi Teaching Hospital during period from December 2015 to May2016.

\section{Collection of urine samples}

Clean-catch midstream urine samples from non pregnant women were collected in a sterile container $(4-5 \mathrm{ml})$ and immediately transport to the laboratory. First step was in urine culture, second step after urine centrifugation $3000 \mathrm{rpm}$ for 10 minute, the supernatant was storage at $-20 \mathrm{C} 0$ until analysis (McFaddin, 2000; SancheziCarbayo, 2000).

\section{Collection of serum sample}

Venous blood samples were collected from non pregnant women; sera were separated by centrifugation of clotted blood at 3000 rpm for 10 minute and stored at deep freeze until analysis (Al-Hakeim, 2008).

\section{Isolation of bacteria}

Urine samples were cultured onto the media Blood and MacConkey agar plate by direct streaking method using a calibrated bacteriological loop measuring $0.001 \mathrm{ml}$ of urine, the inoculated plates were incubated aerobically overnight at $37 \mathrm{C} 0$ and examined growth after 24 hour of incubation ,If no growth was detected, plates were reincubated for another 24 hour before discarding as negative result (Colle et al., 1996). 


\section{Characteristics of culture}

Colonies of isolated bacteria on blood and MacConkey agar plates were described depending on their shape, diameter, color, odor, and other traits. Biochemical tests which achieved for the identification of bacteria were accomplished according to references (Tille, 2014; Pangana and Pangan, 2010; Ryan and Ray, 2004; MacFaddin, 2000).

\section{Diagnostic by API 20E}

Accurate identification tests of bacterial isolates were carried out by api 20 system for Enterobacteriaceae (manufactured by bioMeriex/France) depending on the procedure suggested by the manufacturing company.

Determination of C3 Protein and Immunoglobulins (IgM, IgG, and IgA) by Single Radial Immunodiffusion Plates were provided by Busserio Company (Italy origin)

The checked protein, diffusing in agarose gel involving a particular antibody will form an immune-complex, obvious as a ring around the well. The ring diameter is direct proportion to the level of the studied protein. The proportion relates to the diffusion period in fact, at the end (72) hour.

Detach the plate from its envelope and put to stand at room temperature for few minute in order that any condensed water in the wells can evaporate. Fill the wells with $(5 \mu \mathrm{l})$ of sample and control and wait it has been fully adsorbing before handling the plate. Close the plate and place it in door of the refrigerator for 72 hour. Measure the precipitating ring with an appropriate ruler. Read on enclosed reference table the concentration value corresponding to the precipitating ring diameter.

\section{Statistical analysis}

Statistical analysis to be achieved using the Statistical Package for the Social Science (SPSS), a t-test was used to measure the difference in means between two groups. A value $\mathrm{P} \leq 0.001$ was considered statistically significant.

\section{Results and Discussion}

The results of bacterial growth were involved in 400 urine sample from non pregnant women suffered from some symptoms of UTI on blood and MacConkey agar media showed that (124) urine samples had positive result (significant bacteriuria) for bacterial growth on cultural media in percentage $(31 \%)$, while 276 urine sample showed negative result and absence of bacterial growth on cultural media in percentage $(69 \%)$ from total number. After perform essential biochemical tests and API 20E. Table (1) showed that the highest microorganisms cause UTI was E coli 97 isolate $(78.226 \%)$, the result agree with Chowndhury and Parial (2015) who found that dominant bacteria isolates was $E$ coli (85\%) and disagree with Mousa et al., (2015) who found that common bacteria isolates was Escherichia coli (35\%). Incidence of Klepsiella pneumoniae in this study was $(10.48 \%)$, this result agrees with Chowndhury and Parial (2015) who found the frequency of Klepsiella pneumoniae was (13.5\%). Also the incidence of Proteus spp in this study was $(6.45 \%)$, this result agrees with Mahmood (2011) who found the incidence of Proteus spp (5\%). Incidence of Pseudomonas aeruginosa in the present study was $(4.84 \%)$, the results agree with Kareem and Rasheed (2011) who found the 
Int.J.Curr.Res.Aca.Rev.2016; 4(9): 99-106

frequency of Pseudomonas aeruginosa in women with UTI was (8.75\%).

The results of this study showed significant increased in mean level of serum C3 of women infected by Escherichia coli (195.13 $\pm 10.53) \mathrm{mg} / \mathrm{dl}$ compared with non infected women $(102.74 \pm 6.26) \mathrm{mg} / \mathrm{dl}$ respectively. There was significant difference among the mean levels of complement protein $\mathrm{C} 3$ in the serum of infected women compare to the mean levels of complement protein $\mathrm{C} 3$ in non infected women $(\mathrm{P} \leq 0.001)$.

The mean level of serum complement protein C3 in women infected by Escherichia coli was highly significant compared with women non infected with UTI, this result was in agreement with Essa et al.(2016) who found that level of C3 protein in serum was elevated in pregnant women with UTI, increased C3 protein in serum patients with UTI may return to production of complement proteins by hepatocytes and a number of extrahepatic tissues that involved golmerular epithelial cells (Sacks et al., 1993), endothelial cells (Sheerin et al., 1997), mesangail cells (Van den dobbelsteen et al., 1994) and human proximal tubular epithelial cells (Selvarangan et al., 2000) the C3b fragment which produced by C3 split binds Dr fimbriae expressing on uropathogen $E$ coli then $\mathrm{C} 3 \mathrm{~b}$ binds with Decay accelerating factor (CD55) has been located on the surface of human renal epithelial cells (Selvarangan et al., 2000) CD46 (membrane cofactor protein) can act as a human epithelial cell receptor for entering of opsonized uropathogenic E coli (Li et al., 2006). The raise in serum $\operatorname{IgG}$ in patients with UTI may be the source of the observed increase in the complements in patients group.

Table.1 Numbers and percentages of isolated gram negative enteric bacilli.

\begin{tabular}{|l|c|c|}
\hline Isolated Bacteria & $\begin{array}{c}\text { Number of } \\
\text { Isolates }\end{array}$ & $\%$ \\
\hline Escherichia coli & 97 & 78.23 \\
\hline Klepsiella pneumoniae & 13 & 10.48 \\
\hline Proteus vulgaris & 3 & 2.42 \\
\hline Proteus mirabilis & 5 & 4.03 \\
\hline Pseudomonas aeruginosa & 6 & 4.84 \\
\hline Total & 124 & 100 \\
\hline
\end{tabular}


Int.J.Curr.Res.Aca.Rev.2016; 4(9): 99-106

Table.2 The serum C3 protein level mean among women's group

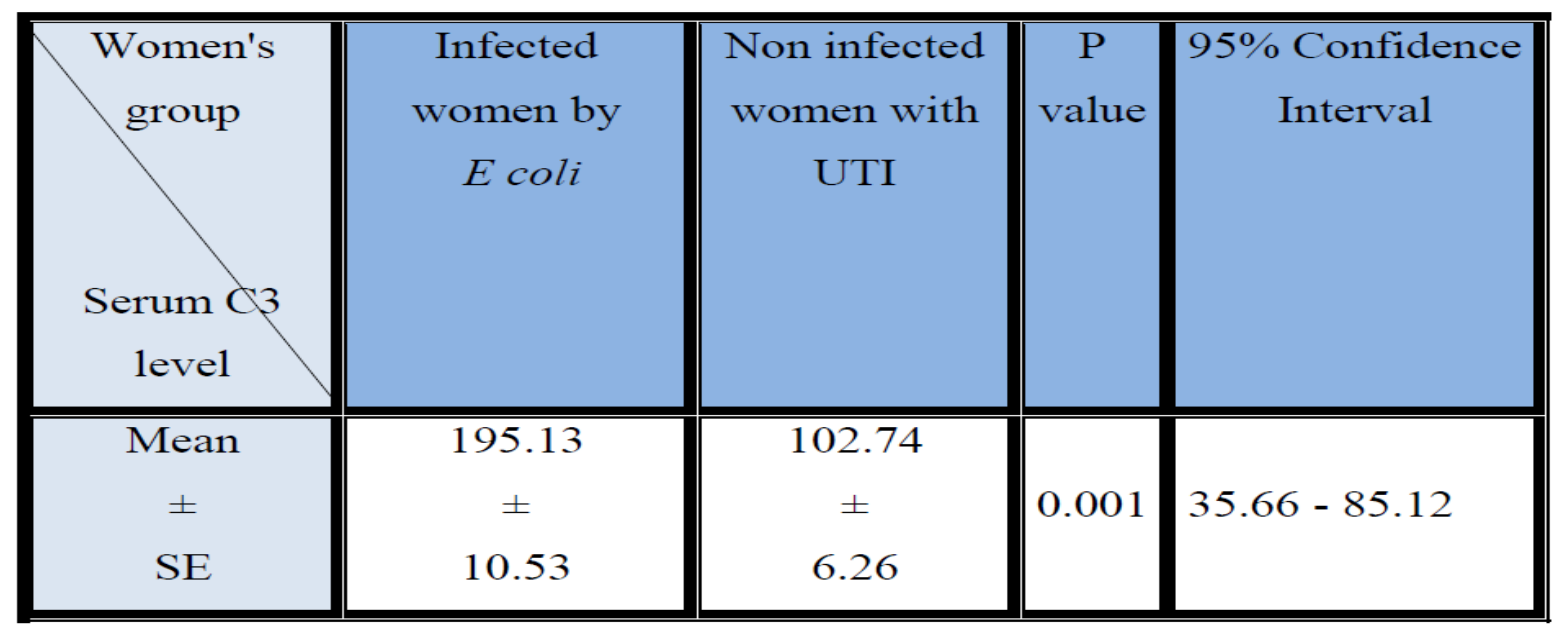

Table.3 The serum Immunoglobulins mean concentration among non pregnant women study

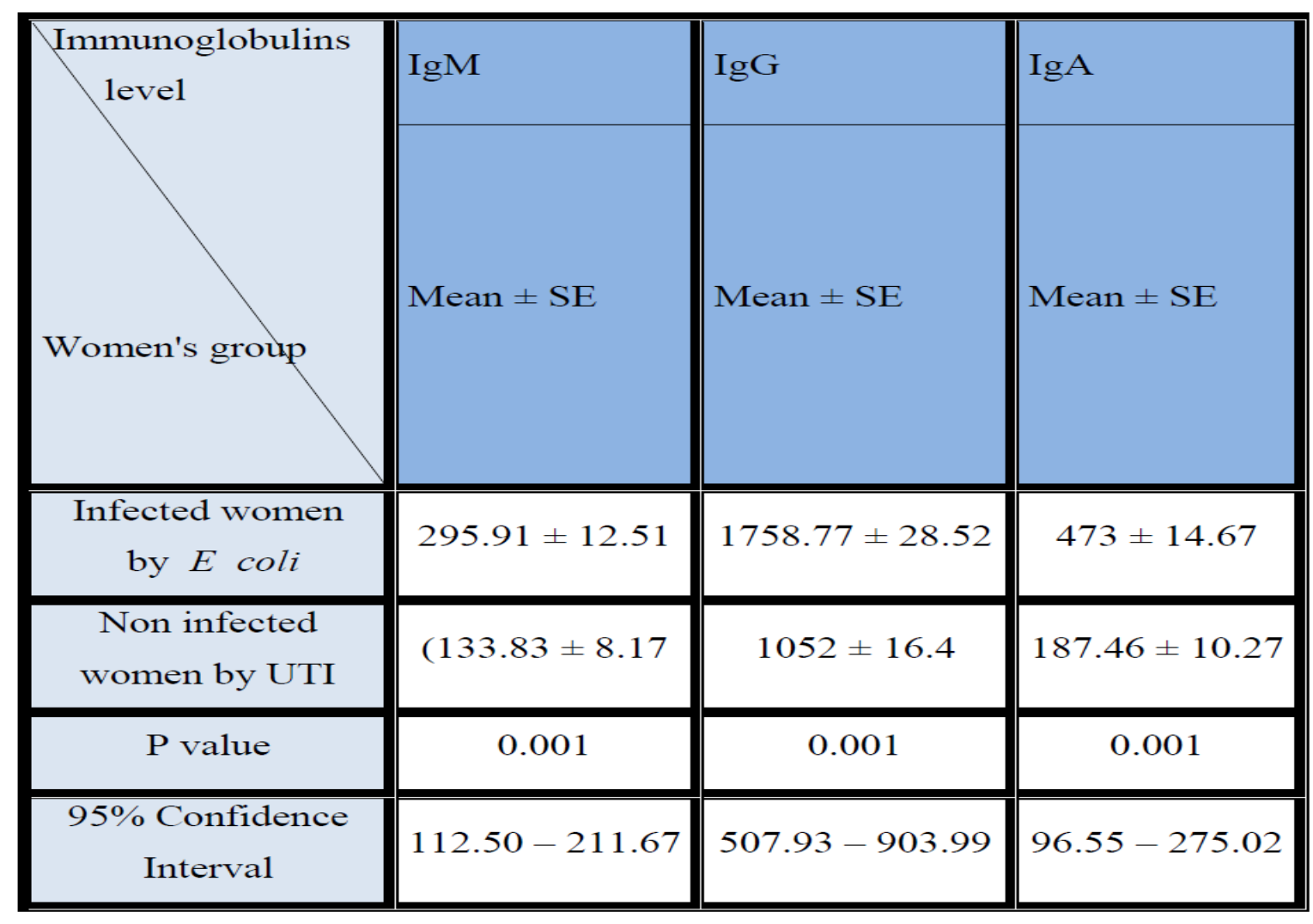

In the current study the results showed significant increased in mean levels of serum IgM, IgG and IgA of women infected by Escherichia coli (295.91 \pm 12.51 , $1758.77 \pm 28.52$ and $473 \pm 14.67) \mathrm{mg} / \mathrm{dl}$ compared with women non infected by UTI $(133.83 \pm 8.17,1052 \pm 16.4$ and 187.46 $\pm 10.27)$ respectively. There was significant difference among the mean levels of immunoglobulins in the serum of infected 
Int.J.Curr.Res.Aca.Rev.2016; 4(9): 99-106

women compare to the mean levels of immunoglobulins in non infected women $(\mathrm{P}$ $\leq 0.001)$.

The mean level of serum immunoglobulins (IgM, IgG and $\operatorname{IgA}$ ) in women infected by Escherichia coli were highly significant compared with women non infected with UTI, this result was in agreement with Ethel et al., (2006) who found that immunoglobulins concentrations in serum were increased in women infected with UTI. Increasing in serum mean levels of immunoglobulins due to activation of $\mathrm{B}$ cell by antigenic stimulation that causing $\mathrm{B}$ cell to divide and differentiates into an antibody producing cell called a plasma cell. Induction of production specific immunoglobulin without the assist of $\mathrm{T}$ lymphocytes for example large molecular weight antigen with regular repeating epitopes involve Pneumococcal polysaccharide, flagellar and fimbrial antigen is $\operatorname{IgM}$ as major antibody, this type of antigen called $\mathrm{T}$ cell independent antigen (Mohanty et al., 2014). Some bacterial antigens can't induce B cell directly for producing immunoglobulins but by helping $\mathrm{T}$ lymphocytes called $\mathrm{T}$ cell-dependent antigen, the switch to other isotypes for example $\operatorname{IgA}$ and $\mathrm{IgG}$, production needs the presence of cytokines and other signals secreted by locally responding $\mathrm{T}$ cells, so two source of immunoglobulins production in patients infected with pathogen has been two type of antigen, these may explain increased in immunoglobulins in non pregnant women infected with gram negative bacilli (Mohanty et al., 2014; Sompayrac, 2012).

\section{References}

Abbas, A.K., Licgtman, A.H. and Pillai, S. 2010. Cellular and Molecular Immunology (6th ed). Philadelphia,
PA: Elsevier/Saunders. USA: 272288.

Al-Hakeim, H.K. 2008. Serum cortisol, Immunoglobulins and some complements among depressed patients. Indian J. Clin. Biochem., 23(1): 76-80.

American Academy of Family Physicians (AAFF). 2004. Urinary Tract Infections: A Common Problem for Women. Review.

Andreas, K., Elisbeth, W., Wareham, K.J. and Monk, P.N. 2013. "International Union of Pharmacology. LXXXVII. Complement Peptide C5a, C4a, and C3a Receptors". Pharmacol. Rev., 65(1): 500-43.

Chowndhury, S. and Parial, R. 2015. Antibiotic Susceptibility of Bacteria among Urinary Tract Infection Patients in Chittagong, Bangladesh. SMU Medical J., 2(1): 114-125.

Collee, J.G., Fraser, A.G., Marmion, B.P. and Simomons, A. 1996." Mackie and McCarthy. Practical Medical Microbiology". 14th ed. Chuchill Livingstone Inc.USA. pp 113-129.

Dromigny, J.A., Nabeth, P., Juergens, B.A. and Perrier-Gros-Claude, J.D. 2005. Risk factors for antibiotic-resistance Escherichia coli urinary tract infection in Dakar; Senegal. J. Antimicrob. Chemother., Volume 56, Issue 1: 236239.

Essa, R.H., Al-Zubiadi, H.K., Rasool, K.H. and Hussein, N.H. 2016. Study of Some Bacteriological and Immunological Parameters in Urinary Tract Infection of Pregnant Women. Research Paper. Vol 2, Issue (1): 8-14.

Ethel, S., Bhat, G.K. and Hegde, B.M. 2006. Bacterial adherence and humoral immune response in women with symptomatic and asymptomatic urinary tract infection. Indian J. Med. Microbiol., 24(1): 30-33. 
Goldman, A.S. and Prabhakar, B.S. 1999. "The Complement System". In Baron $\mathrm{S}$, et al. Baron's Medical Microbiology (4th ed). Univ of Texas Medical Branch. ISBN 0-9631172-1-1.

Janeway, C.A., Travers, P., Walport, M. and Schlomchik, M. 2001. "The complement system and innate immunity". Immunbiology: The Immune System in Health and Disease (5thed). New York: Garland Science.

Kantele, A., Palkola, N., Arvilommi, H., Honkinen, O., Jahnukainen, T. Mertsola, J. and Kantele, J.M. 2008. Local Immune Response to Upper Urinary Tract Infections in Children. Clin. Vacc. Immunol., 15(3): 412-417.

Kareem, I.J. and Rasheed, I.Y. 2001. Antibiotic Susceptibility of Gram Negative Aerobic Bacteria Isolated from Urinary Tract Infection in Community. Iraqi. J. Med. Sci., 9(4): 295- 300.

Kolawole, A.S., Kolawole, O.M., KandakiOlukemi, U.T., Babatunde, S.K., Durowade, K.A. and Kolawole, C.F. 2009. Prevalence of urinary tract infections (UTI) among patients attending Dalhatu Araf Specialist Hospital, Lafia, Nasarawa state, Nigeria. Int. J. Med. Sci., 1(5): 163167.

Lewis, D.A., Gumede, L.Y., Van der hoven, L.A., De Gita, G.N., De Kok, E.D., De Large, T., Maseko, V., Kekana, V., Smuts, F.P. and Perovic, O. 2013. Antimicrobial susceptibility of organisms causing communityacquired urinary tract infections in Gauten Province, South Africa, SAMJ, 103(6): 377-381.

Li, K., Feito M.J., Sacks, S.H. and Sheerin, N.S. 2006. CD46 (membrane cofactor protein) acts as a human epithelial cell receptor for internalization of opsonized uropathogenic Escherichia coli. J. Immunol., 177(4): 2543-2551.

Mahmood, M.A. 2011. Prevalence and Antimicrobial Susceptibility of pathogens in Urinary Tract Infections. J. Al-Nahrain Univ., 14(4): 146-152.

McFaddin, J.F. 2000. Biochemical Tests for Identification of Medical Bacteria. 1st Ed. The Williams and Wilkins. Baltimore, USA.

Mndell, G.L., Bennett, J.E. and Dolin, R. 2005. Principles of infectious diseases, Churchill Livingstone, 881-882.

Mohanty, S.K., Leela, K.S. and Nathsarma, K.C. 2014. Textbook Immunology. 2th ed. Philadelphia-Panama.

Mousa, H.M. and Qasim, M.T. 2015. Microbial Infection and IL-6 Urine Levels for Pregnant women in Thi-Qar Province. World J. Pharma. Res., Vol 4, Issue 05, pp 358-365.

Pangana, K.D. and Pangan, T.J. 2010. Manual of Diagnostic and Laboratory tests. 4th ed. Mosby Elsevier. 21: 952 953.

Ryan, K.J. and Ray, C.G. 2004. Sherris Medical Microbiology. 4th ed. McGraw Hill. USA. 8: 231-240.

Sacks, S.H., Zhou, W., Pani, A., Campbell, R.D. and Martin, J. 1993. Complement C3 gene expression and regulation in human golmerular epithelial cells. Immunol., 79: 348-354.

Sammon, J.D., Shama, P., Rahbar, H., Roghmann, F., Ghani, K.R., Sukumar, S ., Karakiewicz, P.I., Peabody, J.O., Elder, J.S., Menon, M., Sun, M. and Trinh, Q.D. 2014. Rdictors of admission in patients presenting to the emergency department with urinary tract infection. World J. Urol., 32(4): 813-19.

Sanchez-Carbayo, M., Urrutia, M., Conzalez de Buitrago, J.M. and Navajo, J.A. 2000. Evaluation of two new urinary tumor markers: Bladder tumor 
fibronectin and Cytokeratin 18 for diagnosis of bladder cancer. Clin. Canc. Res., 6(9): 3585-3595.

Schappert, S.M. and Rechtsteiner, F.A. 2008. Ambulatory medical care utilization estimates for 2006. Natl. Health. Stat. Report., 8: 1-29.

Selvarangan, R., Goluszko, P., Popov, V., Singhal, J., Pham, T., Lublin, D.M., Nowicki, S. and Nowicki, B. 2000. Role of decay accelerating factor domains and anchorage in internalization of Dr-fimbriated Escherichia coli. Infect. Immunol., 68: 1391-1399.

Sheerin, N.S., Zhou, W., Adler, S. and Sacks, S.H. 1997. TNF-alpha regulation of $\mathrm{C} 3$ gene expression and protein biosynthesis in rat golmerular endothelial cells. Kidney Int., 50: 703710.

Sompayrac, L.M. 2012. How the immune system work. 4th ed John Wiley and Sons, Ltd, UK. pp 42-45.
Stamm, W.E. and Schaeffer, A.J. 2002. The state of the Art in the management of urinary tract infections. Am. J. Med., 113(suppl 1A): 1-84.

Thumbikat, P., Waltenbaugh, C., Schaeffer, A. and Klumpp, D. J. 2006. Antigenspecific responses accelerate bacterial clearance in the bladder. J. Immunol., 176(1): 3080-3086.

Tille, P.M. 2014. Bailey and Scott's Diagnostic Microbiology. 13th ed. Elsever, pp. 193-229.

Van den dobbelsteen, M.E., Verhasselt, V., Kaashoek, J.G., Timmerman, J.J., Schroeijers, W.E., Verweij, C.L., Van der Woude, F.J., Van es, L.A. and Daha, M.R. 1994. Regulation of C3 and factor $\mathrm{H}$ synthesis of human golmerular mesangail cells by IL-1 and interferon-gamma. Clin. Exp. Immunol., 95: 173-180.

\section{How to cite this article:}

Najdat B. Mahdi, Sahla K. Abbas, Khalaf J. Ahmed. 2016. Relationship among Some Immunoglobulins, Complement Protein C3 and Urinary Tract Infection of Women Caused by Gram Negative Bacilli in Kirkuk, Iraq. Int.J.Curr.Res.Aca.Rev.4(9): 99-106. doi: http://dx.doi.org/10.20546/ijcrar.2016.409.009 